\title{
Pengaruh Model Belajar MURDER Terhadap Penguasaan Peserta Didik Di MTs PP Tunas Harapan Tembilahan
}

\author{
Ein Maria Olfa \\ STAI Auliaurrasyidin \\ Tembilahan \\ einmaria.ulfa@email.com
}

\section{Abstrak}

Keberhasilan guru dalam mengajar bukan saja ditentukan oleh strategi pembelajaran dan metode pembelajaran. Hal yang paling mendukung dalam berhasil atau tidaknya proses pembelajaran tersebut amat ditentukan oleh emosional peserta didik. Guru lah yang menentukan dan harus menggiring emosional peserta didik tersebut kearah yang positif sehingga ia siap menerima pembelajaran. Agar proses pembelajaran tersebut dinilai berhasil untuk menggiring peserta didik dalam mencapai tujuan pembelajaran maka diperlukan sebuah cara belajar yang efektif. Salah satu cara yang efektif adalah menggunakan MURDER, MURDER merupakan singkatan dari Mood, Understand, Recall, Digest, Expand dan Review. Tujuan penelitian ini adalah untuk mengetahui Pengaruh Pelaksanaan Belajar MURDER (Mood, Understand, Recall, Digest, Expand, Review) Terhadap Penguasaan Peserta didik Pada Mata Pelajaran Akidah Akhlak di Madrasah Tsanawiyah PPTH Tembilahan. Penelitian ini merupakan penelitian lapangan (field research), dengan menggunakan pendekatan kuantitatif. Subjek dalam penelitian ini adalah guru Akidah Akhlak dan Peserta didik di Madrasah Tsanawiyah PPTH Tembilahan Kecamatan Tembilahan Kabupaten Indragiri Hilir. Hasil penelitian, disapatkan dari pelaksanaan belajar MURDER tersebut maka hasil bahwa $t_{o}$ lebih besar daripada $t$ tabel atau 
J-Al-Mutharahah : Vol. 17 No. 1 Januari-Juni 2020

$2,110<8,37>2,898$ maka hipotesis nihil yang diajukan ditolak berarti berarti adanya pengaruh yang signifikan belajar MURDER (Mood, Understand, Recall, Digest, Expand, Review) terhadap penguasaan peserta didik pada pembelajaran.

\section{Abstract.}

The success of a teacher in teaching is not only determined by learning strategies and methods. The most supportive success thing or failure of the learning process is a lot of determined by students' emotions. The teacher is one who determines and leads the learner's emotions towards positive so that they have to accept learning already. Then, the learning process is considered successful to lead students in achieving learning objectives, we need an effective way of learning. One effective way is to use MURDER, MURDER is an abbreviation of Mood, Understand, Recall, Digest, Expand, and Review. The purpose of this study was to determine the Effect of Learning Implementation of MURDER (Mood, Understand, Recall, Digest, Expand, Review) Against Student Mastery in Moral Aqeedah in Tsanawiyah Tsanawiyah PPTH Tembilahan Madrasah. This research is field research (field research), using a quantitative approach. The subjects in this study were the teachers of the moral creed and students in the Tsanawiyah PPTH Madrasah Tembilahan, Tembilahan District, Indragiri Hilir Regency. The results of the study, obtained from the implementation of the MURDER learning, the results that t_o is greater than $t$ table or $2.110<8.37>2.898$ then the null hypothesis proposed is rejected, meaning that there is a significant influence of MURDER learning (Mood, Understand, Recall, Digest, Expand, Review) on the mastery of students in learning. 
J-Al-Mutharahah : Vol. 17 No. 1 Januari-Juni 2020

\section{Kata Kunci: MURDER, Penguasaan}

Keywords: MURDER, Power of attorney

\section{A. PENDAHULUAN.}

\section{Pendahuluan}

Proses pembelajaran terjadi karena adanya interaksi antara peserta didik dan pendidik dalam suatu lingkungn beajar. Hal ini senada dengan yang dikatakan oleh Sutikno "pembelajaran" adalah sebuah sistem lingkungan belajar yang di dalamnya terdapat tujuan pembelajaran, materi pembelajaran, kegiatan belajar mengajar, serta terdapat metode, media, sumber belajar dan evauasi belajar. ${ }^{1}$ Untuk meningkatkan hasil belajar guru menggunakan model, strategi dalam pelaksanaan belajar yang dirancang agar dapat memberikan hasil yang memuaskan bagi peserta didik. Dalam proses mengajar seorang guru juga harus menguasai beberapa keterampilan dalam rangka mensukseskan pembelajaran tersebut, diantaranya dapat berupa keterampilan menyiapkan bahan pelajaran, menyusun satuan pembelajaran, dan menggunakan alat pembelajaran dan menggunaan model pembelajaran yang tepat. $^{2}$

Proses pembelajaran terjadi karena berbagai aspek yang saling berkaitan, Wina Sanjaya menjelaskan bahwa proses belajar mengajar terlaksana jika terjadi kerja sama antara guru dan peserta didik dan didukung dengan segala potensi yang dimiliki peserta didik seperti bakat dan minat termasuk gaya belajar dan didukung dengan sarana dalam

\footnotetext{
${ }^{1}$ Sutikno, Belajar dan Pembelajaran, (Bandung: Prospect, 2008), hlm. 31.

${ }^{2}$ Roestiyah NK. Strategi Belajar Mengajar. (Jakarta: Rineka Cipta. 2001). hlm. 7.
} 
proses pembelajaran untuk mencapai keberhasilan dalam

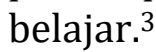

Keberhasilan dalam mengajar tersebut bukan saja ditentukan oleh strategi pembelajaran dan metode pembelajaran. Hal yang paling mendukung dalam berhasil atau tidaknya proses pembelajaran amat ditentukan oleh emosional peserta didik. Guru yang menentukan dan harus menggiring emosional peserta didik kearah yang positif sehingga siap menerima pembelajaran. Agar proses pembelajaran dinilai berhasil untuk menggiring peserta didik dalam mencapai tujuan pembelajaran maka diperlukan sebuah cara belajar yang efektif. Salah satu cara yang efektif adalah menggunakan MURDER, MURDER merupakan singkatan dari mood, understand, recall, digest, expand, dan riview. Mood adalah suasana hati, dalam proses pembelajaran diupayakan menjadi pembelajaran yang menyenangkan dapat dilakukan dengan menata ruangan belajar, mengelola pembelajaran, memotivasi peserta didik agar bersemangat, memanfaatkan media dan sumber belajar yang relevan. ${ }^{4}$ Understand adalah pemahaman. Recall artinya pengulangan. Digest artinya penelaahan. Dalam proses pembelajaran dan peserta didik harus menelaah kembali apa yang diajarkan. Expand artinya pengembangan. Review atau mempelajari kembali.

Jika dilihat dari epistemologi dari MURDER di atas maka jika pembelajaran dilaksanakan dengan baik sesuai dengan prosedur MURDER, maka akan ada peningkatan yang signifikan dalam pembelajaran dan memberikan efek positif terhadap terhadap kondisi dan lingkungan belajar peserta didik. Oleh sebab itu model pembelajaran MURDER

${ }^{3}$ Wina Sanjaya. Perencanaan dan Desain Pembelajaran. (Jakarta: Media Group. 2009). hlm. 26.

${ }^{4}$ Ibid., hal. 132 
J-Al-Mutharahah : Vol. 17 No. 1 Januari-Juni 2020

menjadi sangat perlu untuk diterapkan dalam proses mengajar belajar.

Dalam proses pembelajaran sering sekali dijumpai berbagai permasalahan apakah hal itu disebabkan oleh lingkungan ataupun stategi metode yang digunakan guru dalam proses pembelajaran yang dapat mengurangi mood atau suasana hati peserta didik yang hal ini akan berdampak kepada proses pembelajaran. Oleh sebab itu guru sebaiknya tidak hanya mementingkan metode dan strategi namun hal lain seperti mood peserta didik dan membangkitkan gairah dalam belajar harus diperhatikan.

\section{KERANGKA TEORI MURDER}

Keberhasilan proses belajar mengajar ditentukan dari cara dan model mengajar guru di kelas, hal ini pada umumnya tergantung bagaimana persepsi guru tentang mengajar dan pembelajaran itu sendiri dalam mengemas pembelajaran. Jika seorang guru berpersepsi bahwa mengajar adalah mentransfer ilmu pengetahuan kepada peserta didik maka dalam belajar guru menempatkan peserta didik sebagai tempat yang harus diisi guru, dalam prakteknya guru menjelaskan materi pembelajaran dan peserta didik hanya memperhatikan. Setelah pembelajaran berakhir peserta didik akan diuji kemampuannya sebagai bukti keberhasian penyampaian materi guru jika peserta didik tidak mampu memberikan jawaban benar maka kesalahan akan ditimpakan kepada peserta didik. Pada sisi lain jika seorang guru berpersepsi belajar adalah sebuah perubahan maka guru akan menempatkan peserta didik sebagai manusia yang berada dalam proses perkembangan yang memerlukan bimbingan. Sehingga dalam prakteknya jika terjadi kesalahan dalam proses pembelajaran maka kesalahan cenderung tidak semata disalahkan kepada peserta didik. Oleh sebab itu model pembelajaran sangat 
berpengaruh terhadap hasil belajar peserta didik. Untuk mengembangkan belajar aktif dan dapat meningkatkan penguasaan peserta didik dalam belajar dengan model belajar MURDER.

\section{a. Mood (Suasana Hati)}

Mood (Suasana hati) merupakan kondisi emosional yang menyebabkan seseorang bereaksi negatif terhadap sesuatu disekitarnya, yang akan memperngaruhi respons seseorang tehadap stimulasi emosi yang diterimanya. Dalam proses pembalajaran mood sangat berpengaruh kepada keberhasilan belajar. Suasana hati mengarah kepada ranah kecerdasan emosional yang berkaitan dengan rasa senang, gembira, sedih, rasa kecewa. Ranah suasana hati umum juga memiliki dua skala, yaitu sebagai berikut:

a) Optimisme, yaitu kemampuan seseorang dalam mempertahankan sikap positif dalam menghadapi situasi sulit. Dalam pengertian luas optimis berarti orang yang mampu berpandangan baik dalam menghadapi segala hal.

b) Kebahagiaan, yaitu kemampuan mensyukuri kehidupan, mencintai diri sendiri. Kebahagiaan berhubungan dengan rasa riang dan penuh semangat. Kebahagiaan merupakan suatu keadaan pikiran atau perasaan yang ditandai dengan kesenangan, kecintaan, kepuasan, kenikmatan yang dirasakan. ${ }^{5}$

Pada tahap mood ini, guru menciptakan suasana hati yang positif kepada peserta didik dengan memberi semangat mengikuti pembelajaran. Hal ini merupakan

${ }^{5}$ Hamzah B. Uno, Orientasi Baru Dalam Psikologi Pembelajaran. (Jakarta: PT. Bumi Aksara, 2006), hlm. 82 
proses awal untuk memenangkan hati peserta didik agar tertarik mengikuti tahap-tahap berikutnya. Guru dapat menggunakan beberapa hal seperti mengatur kelas yang nyaman dan kebersihan. ${ }^{6}$ Dengan kelas yang bersih dan suasana hati yang baik peserta didik akan mudah mengoptimalkan kemampuannya dalam proses pembeajaran karena kualitas dan kuantitas belajar peserta didik di dalam kelas dipengaruhi beberapa faktor seperti kemampuan guru, hubungan timbal balik guru dan peserta didik serta kondisi dan suasana kelas. ${ }^{7}$

\section{Understand (Pemahaman)}

Pemahaman dalam proses pembelajaran ditandai dengan peserta didik mampu menjelaskan dengan susunan kalimatnya sendiri dari sesuatu yang dibaca atau yang didengarnya memperluas persepsi dari sebuah masalah, menyelesaikan permasalahan dengan penafsiran. ${ }^{8}$ Pada tahap understand ini, peserta didik harus mampu memahami apa yang telah dipelajari, guru memberikan stimulus dengan menggunakan materi, memanfaatkan media dalam proses pembelajaran. Untuk melihat tingkat pemahaman peserta didik guru memberikan sebuah permasalahan dan melihat kemampuan peserta didik dalam mengembangkan persepsinya terhadap apa yang telah dibaca.

${ }^{6}$ Wina Sanjaya, Strategi Pembelajaran Berorientasi Standart Proses Pendidikan, (Jakarta: Kencana Prenada Media, 2006), hlm. 134

7Rusman, Model-Model Pembelajaran mengembangkan profesional guru, edisi kedua, (Jakarta, PT. Raja Grafindo Persada. 2012), hlm. 63

${ }^{8}$ Nana Sudjana, Penilaian Hasil Belajar Mengajar, (PT. Remaja Rosdakarya: Bandung, 2001) hlm. 24 


\section{Recall (Pengulangan)}

Pada tahap ini diperlukan bantuan guru dengan memberikan pertanyaan baik langsung maupun secara tertulis untuk melihat kemampuan peserta didik dalam mengulang materi.

Hasil dari sebuah pemahaman adalah peserta didik mampu menguang kembali apa yang telah dipelajari. Proses belajar dikatakan berhasil jika seseorang mampu mengulangi kembali materim kemudian mampu menyampaikan dalam bahasa. ${ }^{9}$ Merecall tidak hanya berupa pengetahuan tentang fakta, tetapi juga mengingat akan konsep yang luas, generalisasi yang telah didistribusikan, definisi, metode dalam mendekati masalah. Tujuan dari mengulang adalah agar peserta didik memiliki kesempatan untuk membentuk atau menyusun kembali informasi yang telah mereka terima. ${ }^{10}$ Pengulangan juga merupakan Penyajian materi kembali bagi peserta didik yang belum memahami materi yang dipelajarinya. Prosedur pengulangan yang paling umum adalah mengulangi informasi yang pernah dipelajari peserta didik. ${ }^{11}$

\section{Digest (Penelaahan)}

Dalam kamus bahasa Indonesia penelaahan berasal dari kata telaah yang berarti penyidikan, pemeriksaan. Menelaah berarti proses mempelajari,

${ }^{9}$ Syaiful Sagala, Konsep dan Makna Pembelajaran, (Bandung: Alfabeta, 2003) hlm. 13

${ }^{10}$ Syaiful Bahri Jamarah, Guru dan Anak Didik Dalam Interaksi Edukatif, (Jakarta: Asdi Mahasatya, 2005), hlm. 108

${ }^{11}$ Rusman, Model-Model Pembelajaran mengembangkan profesional guru, edisi kedua, (Jakarta, PT. Raja Grafindo Persada. 2012, hlm. 308 
menyelidiki dan memeriksa. ${ }^{12}$ Dari definisi tersebut dapat dipahami bahwa peserta didik mengkaji materi yang diajarkan dari sumber ain seperti buku, majalah, internet untuk mengembangkan materi.

Pada tahap ini guru meminta peserta didik menelaah kembali kebenaran dari materi yang diberikan dari sumber lain sebagai pemahaman konsep.

\section{Expand (Pengembangan)}

Pada tahap pengembangan guru meminta peserta didik mengembangkan materi. Hal ini dapat dilaksanakan dengan berdiskusi sehingga peserta didik dapat mencermati dan menganalisis hasil pemecahan masalah. Dengan proses ini dapat diketahui pemasalahan dan meningkatkan pemahaman lebih optimal.

Pengembangan merupakan hasil kumulatif dari pada pembelajaran. Hasil dari proses pembelajaran adalah perubahan perilaku peserta didik. Individu akan memperoleh perilaku yang baru, menetap, fungsional, positif, didasari dan sebagainya. Hasil belajar atau bentuk perubahan tingkah laku meliputi tiga aspek, yaitu: pertama aspek kognitif, meliputi perubahan-perubahan dalam segi penguasaan pengetahuan dan perkembangan keterampilan/kemampuan yang diperlukan untuk menggunakan pengetahuan tersebut, kedua aspek afektif, meliputi perubahan-perubahan dari segi mental, perasaan dan kesadaran, dan ketiga aspek

12Pusat Pembinaan $\mathrm{n}$ Pengembangan Bangsa, Kamus Besar Bahasa Indonesia, (Departemen Pendidikan dan Kebudayaan: Balai Pustaka), hlm. 917 
psikomotor, meliputi perubahan-perubahan dalam segi bentuk-bentuk tindakan motorik ${ }^{13}$.

\section{Review (Pelajari Kembali)}

Pada tajap terakhir ini peserta didik meninjau kembali, mempelajari kembali seluruh materi yang telah dipelajari. ${ }^{14}$ Jika informasi yang dipelajari dapat diingat dan dipahami dengan baik. Peserta didik mampu menghubungkan materi dengan berbagai situasi berdasarkan pembelajaran yang telah didapatkan.

Model pembelajaran MURDER dapat meningkatkan penguasaan peserta didik dalam memahami materi pembelajaran dengan membangun suasana belajar yang menyenangkan sehingga membantu peserta didik lebih aktif dalam mengikuti pembelajaran.

\section{B. METODE PENELITIAN}

Penelitian ini merupakan jenis penelitian lapangan (field research) dengan metode kuantitatif. Penelitian dilaksanakan selama tiga bulan terhitung dari bulan Februari 2019 sampai Mei 2019. Penelitian ini berlokasi di Madrasah Tsanawiyah Pondok Pesantren Tunas Harapan Tembilahan Kecamatan Tembilahan Kabupaten Indragiri Hilir. Subjek dalam penelitian ini adalah guru Akidah Akhlak dan peserta didik. Metode pengumpulan data yang dipakai dalam penelitian ini yaitu: Studi dokumentasi, Observasi, Tes. Analisis data yang digunakan dalam penelitian ini dilakukan dengan mengoah data

13Zakiah Daradjat, Pengajaran Agama Islam, (Jakarta: Bumi Aksara, 2004), hlm. 197

${ }^{14}$ Syaiful Sagala, Konsep dan Makna Pembelajaran, (Bandung: Alfabeta, 2003) hlm. 60 
J-Al-Mutharahah : Vol. 17 No. 1 Januari-Juni 2020

menggunakan rumus statistik, data-data dikumpulkan dari hasil tes dengan rumus uji t sebagai berikut:

$$
t_{o}=\frac{M_{D}}{S E_{M_{D}}}
$$

\section{PEMBAHASAN}

Dari hasil penelitian penulis membandingkan hasil belajar peserta didik dari sebelum menggunakan model pembelajaran MURDER dan sesudah menggunakan model pembelajaran MURDER. Maka dapat dipahami peserta didik yang menggunakan model pembelajaran MURDER pada pembelajaran Aqidah Akhlak realistik menghasilkan nilai yang lebih baik. hal ini dilihat dari hasil akhir pembelajaran dengan hasil perolehan nilai rata-rata sebelum 1091,5 sedangkan nilai rata-rata setelah menggunakan MURDER 1462,9.

Berdasarkan hasil standar perbedaan skor variabel $\mathrm{x}$ dan y untuk itu uji $t$ dapat dilakukan. Hasi hipotesis diperoleh bahwa Ho ditolak dan Ha diterima artinya ratarata penguasaan peserta didik yang menggunakan model pembelajaran MURDER lebih tinggi dari rata-rata kemampuan penguasaan yang menggunakan model pembelajaran konvensional, berarti dari hasil penelitian terdapat pengaruh yang signifikan model beajar MURDER terhadap penguasaan peserta didik pada mata pelajaran Aqidah Akhlak. Adapun penjelasan proses pembelajaran, sebagai berikut:

Langkah yang dilakukan guru dalam proses pembelajaran menggunakan mode pembelajaran MURDER adalah sebagai berikut: 
J-Al-Mutharahah : Vol. 17 No. 1 Januari-Juni 2020

\section{Tabel 2}

Langkah-Langkah MURDER

\begin{tabular}{|c|c|}
\hline Langkah & Aktivitas \\
\hline Mood (suasana hati) & $\begin{array}{l}\text { - } \begin{array}{l}\text { Memberikan motivasi, } \\
\text { semangat } \\
\text { memulai belajar }\end{array} \\
\text { - Membentuk kelompok } 3 \\
\text { sampai 4 orang }\end{array}$ \\
\hline Understand (memahami) & $\begin{array}{l}\text { - Membaca materi tanpa } \\
\text { menghafal dan fokus pada } \\
\text { tugas } \\
\text { - Guru menjelaskan singkat } \\
\text { materi }\end{array}$ \\
\hline $\begin{array}{l}\text { Recall } \quad \text { (mengingat } \\
\text { kembali) }\end{array}$ & $\begin{array}{ll}\text { - } & \text { Guru memberikan } \\
\text { pertanyaan-pertanyaan } \\
\text { - } & \text { Peserta didik } \\
\text { mengerjakan soal di LKS }\end{array}$ \\
\hline Digest (penelaahan) & $\begin{array}{l}\text { - Mencari sumber materi } \\
\text { dari buku dan internet }\end{array}$ \\
\hline Expand (pengembangan) & 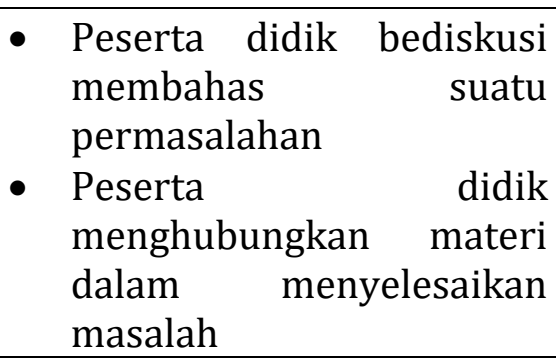 \\
\hline $\begin{array}{l}\text { Riview } \quad \text { (mempelajari } \\
\text { kembali) }\end{array}$ & $\begin{array}{l}\text { Guru dan peserta didik } \\
\text { melakukan refleksi membuat } \\
\text { kesimpulan dari materi yang } \\
\text { telah dipelajari }\end{array}$ \\
\hline
\end{tabular}

Proses pembelajaran yang dilakukan pada kelas eksperimen dengan menerapkan model pembelajaran MURDER menggunakan langkah-langkah di atas pada 
pertemuan pertama guru membagi kelompok peserta didik dan mulai memberikan hal yang berbeda dengan memberikan motivasi, menarik perhatian peserta didik dengan menggunakan vidio, mengajak peserta didik mengenal makna pembelajaran yang aktif dan menyenangkan. Pada situasi ini terihat peserta didik antusias dengan stimulus yang diberikan guru. Setelah mendapatkan suasana yang baik peserta didik mulai diberikan materi, peserta didik membaca dan mendengarkan penjelasan guru. Pada tahap ini terlihat peserta didik dengan seksama membaca dan mendengarkan penjelasan guru. Untuk menilai daya tangkap pemahaman peserta didik guru memberikan beberapa pertanyaan secara lisan yang berkaitan dengan materi, peserta didik terlihat antusias dalam menjawab pertanyaan. Dari jawaban peserta didik guru dapat menilai tingkat pemahaman materi yang telah dipelajari. Pada tahap selanjutnya peserta didik mulai berdiskusi dengan diberikan beberapa permasalahan pada materi dan peserta didik diperbolehkan mencari materi diberbagai sumber hal ini menambah semangat peserta didik dengan mencari data di buku dan di internet dengan menggunakan handphone. Terihat peserta didik antusias dalam menelaah materi. Setelah melakukan penelaahan peserta didik mulai mengembangkan materi dengn membahas bersama-sama di kelas pada kelompok yang ditunjuk untuk menjelaskan materi. Pada tahap ini terlihat peserta didik antusias dalam menjawab mengembangkan jawaban penyelesaian masalah dari berbagai sumber yang telah didapatkan. Akhir dari petemuan peserta didik dan guru memberi kesimpuan apa yang telah dipeajari. Berdasarkan proses pembelajaranyang dilakukan terlihat peserta didik banyak mendapatkan informasi sesuai dengan usaha masing- 
masing dan lebih banyak pertanyaan yang muncul sehingga proses pembelajaran lebih menyenangkan.

Pada proses pembelajaran MURDER lebih terlihat aktivitas peserta didik dalam berdiskusi yang mencari informasi sehingga memudahkan guru dalam mengecek kemampuan penguasaan peserta didik. Pada model ini proses pembelajaran tidak berpusat kepada guru, peserta didik dituntut lebih aktif. Jika dibandingkan dengan pembelajaran pada kelas kontrol dengan menggunakan model kovensional peserta didik kurang aktif dalam bertanya karena didominasi oleh guru yang memberikan materi sehingga peserta didik tidak terlihat antusias dalam proses pembelajaran karena proses pembelajaran berpusat pada guru peserta didik mendengarkan dan mencatat matei yang dijeaskan oleh guru. Oleh sebab itu, maka mode pembelajaran sangat berpengaruh kepada tingkat keaktifan dan penguasaan materi peserta didik. Model pembelajaran MURDER memiliki keunggulan menciptakan suasana yang menyenangkan dalam proses belajar sehingga memudahkan peserta didik dalam memahami materi.

Untuk mengetahui pengaruh belajar MURDER terhadap penguasaan peserta didik kita dapat mengambil nilai berdasarkan nilai-nilai hasil belajar peserta didik dari sebelum dan sesudah pengguanaan MURDER, sebagai berikut: 
J-Al-Mutharahah : Vol. 17 No. 1 Januari-Juni 2020

\section{Tabel 1}

Tabel Penolong Statistik

\begin{tabular}{|l|l|l|l|l|}
\hline No & $\begin{array}{c}\text { Sebelum } \\
\text { diterapkan } \\
\text { MURDER }\end{array}$ & $\begin{array}{c}\text { Sesudah } \\
\text { diterapkan } \\
\text { MURDER }\end{array}$ & \multicolumn{1}{|c|}{$\begin{array}{c}\text { D }= \\
\text { (X-Y) }\end{array}$} & D $^{\mathbf{2}}$ \\
\hline 1 & 60 & 80 & -20 & 400 \\
\hline 2 & 62,5 & 76,6 & $-41,1$ & 1689,2 \\
\hline 3 & 69 & 76,6 & $-7,6$ & 57,76 \\
\hline 4 & 57 & 81,6 & $-24,6$ & 605,2 \\
\hline 5 & 70 & 75 & -5 & 25 \\
\hline 6 & 42,5 & 86,6 & $-44,1$ & 1944,8 \\
\hline 7 & 56,5 & 87,5 & -31 & 961 \\
\hline 8 & 49 & 82,5 & $-33,5$ & 1122,3 \\
\hline 9 & 62,5 & 87,5 & $-29,5$ & 870,3 \\
\hline 10 & 65 & 75 & -10 & 100 \\
\hline 11 & 62,5 & 90 & $-27,5$ & 756,3 \\
\hline 12 & 67,5 & 87,5 & -20 & 400 \\
\hline 13 & 65 & 85 & -20 & 400 \\
\hline 14 & 60 & 76,7 & $-16,7$ & 278,9 \\
\hline 15 & 60 & 76,6 & $-16,6$ & 275,6 \\
\hline 16 & 57,5 & 81,6 & $-24,1$ & 580,8 \\
\hline 17 & 70 & 75 & -5 & 25 \\
\hline 18 & 55 & 81,6 & $-26,6$ & 707,6 \\
\hline & 1091,5 & 1462,9 & & $\sum D^{2}=9463,8$ \\
& & & $\sum \mathrm{D}=-371,4$ & 6 \\
\hline
\end{tabular}

Dari tabel di atas, dapat diketahui bahwa:

$$
\begin{array}{|l|l|}
\hline \sum \mathrm{D}=-371,4 & \sum \mathrm{D}^{2}=9463,86 \\
\hline
\end{array}
$$

Dengan diketahui $\sum \mathrm{D}$ dan $\sum \mathrm{D}^{2}$, maka dapat dicari deviasi Standar Perbedaan Skor antara variabel $\mathrm{X}$ dan variabel $\mathrm{Y}\left(\mathrm{SD}_{\mathrm{D}}\right)$ : 
J-Al-Mutharahah : Vol. 17 No. 1 Januari-Juni 2020

$$
\begin{aligned}
& \mathrm{SD}_{\mathrm{D}}=\sqrt{\frac{\sum D^{2}}{N}-\left[\frac{\sum D}{N}\right]^{2}} \\
& \mathrm{SD}_{\mathrm{D}}=\sqrt{\frac{9463,86}{18}-\left[\frac{-371,4}{18}\right]^{2}} \\
& \mathrm{SD}_{\mathrm{D}}=\sqrt{525,77-(-20,6)^{2}} \\
& \mathrm{SD}_{\mathrm{D}}=\sqrt{525,77-424,36} \\
& \mathrm{SD}_{\mathrm{D}}=\sqrt{101,41}=10,1 \\
& \mathrm{SD}_{\mathrm{M}_{\mathrm{D}}}=\frac{\mathrm{SD}_{\mathrm{D}}}{\sqrt{N-1}}=\frac{10,1}{\sqrt{18-1}}=\frac{10,1}{\sqrt{17}}=\frac{10,1}{4,1}=2,46
\end{aligned}
$$

Langkah selanjutnya adalah mencari $t_{o}$ harga dengan menggunakan rumus:

$$
t_{o}=\frac{M_{D}}{S E_{M_{D}}}=\frac{20,6}{2,46}=8,37
$$

Langkah berikutnya, diberikan interprestasi terhadap $t_{o}$ dengan memperhitungkan $\mathrm{df}$ atau db-nya: $\mathrm{df}$ atau $\mathrm{db}=\mathrm{N}-1$ $=18-1=17$. Dengan df sebesar 17 berkonsultasi pada nilai " $\mathrm{t}$ " baik pada taraf signifikansi $5 \%$ maupun pada taraf signifikansi $1 \%$. Sehingga diperoleh $\mathrm{t}$ tabel pada taraf signifikansi $5 \%$ sebesar 2,110 sedangkan pada taraf signifikansi 1\% diperoleh sebesar 2,898.

Dengan membandingkan besarnya " $\mathrm{t}$ " yang diperoleh dalam perhitungan $t_{o}=6,387$ dengan $t$ tabel maka didapat: 1

$$
2,110<8,37>2,898
$$

Karena $t_{o}$ lebih besar daripada $\mathrm{t}$ tabel maka hipotesis nihil (Ho) yang diajukan ditolak dan hipotesis alternatif (Ha) diterima. berarti adanya pengaruh yang signifikan belajar MURDER (Mood, Understand, Recall, Digest, Expand, Review) terhadap penguasaan peserta didik pada pembelajaran Aqidah Akhlak di Madrasah Tanawiyah Pondok Pesantren Tunas Harapan Tembilahan. 
J-Al-Mutharahah : Vol. 17 No. 1 Januari-Juni 2020

\section{KESIMPULAN}

Berdasarkan hasil penelitian yang dilakukan, maka ditarik kesimpulan sebagai berikut: $t_{o}$ lebih besar daripada $t$ tabel atau 2,110 < 8,37>2,898 maka hipotesis nihil yang diajukan ditolak berarti adanya pengaruh yang signifikan belajar MURDER (Mood, Understand, Recall, Digest, Expand, Review) terhadap penguasaan peserta didik pada pembelajaran Aqidah Akhlak di Madrasah Tanawiyah Pondok Pesantren Tunas Harapan Tembilahan. Dalam proses pembelajaran dapat disimpulkan pula guru Akidah Akhlak dapat menggunakan cara belajar MURDER dengan baik dalam proses belajar mengajar, dengan menguasai teknik-teknik pelaksanaan pembelajaran menggunakan MURDER dapat memudahkan anak didik paham dan menguasai materi yang telah dipelajari.

\section{E. REFERENSI}

Colin Rose. 1999. Kuasai Lebih Cepat. Bandung: Kaifa.

Hamzah B. Uno. 2006. Orientasi Baru Dalam Psikologi Pembelajaran. Jakarta: PT. Bumi Aksara.

Mohammad Surya. 2004. Psikologi Pembelajaran dan Pengajaran. Jakarta: Pusataka Bani Quraisy.

Muhibbin Syah. 2010. Psikologi Pendidikan dengan

Pendekatan Baru. PT. Raja .Rosdakarya: Bandung.

Nana Sudjana. 2001. Penilaian Hasil Belajar Mengajar. PT. Remaja Rosdakarya: Bandung.

Rusman. 2012. Model-Model Pembelajaran mengembangkan profesional guru, edisi kedua, Jakarta, PT. Raja Grafindo Persada.

Sutikno. 2008. Belajar dan Pembelajaran. Bandung: Prospect.

Roestiyah NK. 2001. Strategi Belajar Mengajar. Jakarta: Rineka Cipta. 
J-Al-Mutharahah : Vol. 17 No. 1 Januari-Juni 2020

Syaiful Bahri Jamarah. 2005. Guru dan Anak Didik Dalam Interaksi Edukatif. Jakarta: Asdi Mahasatya.

Syaiful Bahri Djamarah dan Aswan Zain. 2010. Strategi Belajar Mengajar. Jakarta: PT. Renika Cipta.

Syaiful Sagala. 2003. Konsep dan Makna Pembelajaran. Bandung: Alfabeta.

Wina Sanjaya. 2006. Strategi Pembelajaran Berorientasi Standar Prose Pendidikan. Jakarta: Kencana Prenada Media.

2009. Perencanaan dan Desain Pembelajaran. Jakarta: Media Group.

Zakiah Daradjat. 2004. Pengajaran Agama Islam. Jakarta: Bumi Aksara. 